\title{
ILRReview
}

2-13-2013

\section{The Hidden Costs of High-Performance Work Practices: Evidence from a Large German Steel Company}

Bernd J. Frick

University of Paderborn, bernd.frick@notes.upb.de

Ute Goetzen

University of Applied Sciences Dresden, gleichstellung@htw-dresden.de

Robert Simmons

LancasterUniversity, r.simmons@lancaster.ac.uk 


\title{
The Hidden Costs of High-Performance Work Practices: Evidence from a Large German Steel Company
}

\begin{abstract}
The authors use monthly data from 25 production units in a German steel plant over the period 1992 to 2001 to test for impacts of teamwork and performance-related pay on productivity, accidents, and absence rates. They find that teamwork and performance pay provide incentives to workers to increase quantity at the expense of quality and to run the machines for long hours instead of spending time on maintenance. Absenteeism increases when a combination of teamwork and performance pay is applied to production units that previously had neither. Results suggest that teamwork and performance pay can create hidden costs for manufacturers and do not necessarily increase worker productivity.
\end{abstract}

\section{Keywords}

teamwork, performance pay, productivity, absenteeism, workplace accidents

\section{Cover Page Footnote}

We would like to thank the Hans Boeckler Foundation in Duesseldorf for generously funding this project, and the workers and managers of "Company X" for answering our questions. The data we use are proprietary and cannot be made available to other researchers. We will, however, provide a detailed description of the data sets and additional econometric analyses upon request. We are grateful to the editors, Tove Hammer and Lawrence Kahn, as well as two anonymous referees for their helpful and constructive comments and suggestions. Department of Management, University of Paderborn, Warburger Strasse 100, 33098 Paderborn, Germany. E-mail: bernd.frick@notes.upb.de, Institute for Labor and Personnel Economics, Mobile Life Campus, Volkswagen AG, Hermann-Muench-Strasse 1, 38440 Wolfsburg, Germany and Institute of Labour Law and Industrial Relations in the European Community, Campus II, University of Trier, 54286 Trier, Germany. Institute for Labor and Personnel Economics, Mobile Life Campus, Volkswagen AG, HermannMuench-Strasse 1, 38440 Wolfsburg, Germany. Email: ute.goetzen@volkswagen.de. Department of Economics, The Management School, Lancaster University, Lancaster LA1 4YX, UK. Email: r.simmons@lancaster.ac.uk. 


\title{
THE HIDDEN COSTS OF HIGH-PERFORMANCE WORK PRACTICES: EVIDENCE FROM A LARGE GERMAN STEEL COMPANY
}

\author{
BERND J. FRICK, UTE GOETZEN, AND ROBERT SIMMONS*
}

The authors use monthly data from 25 production units in a German steel plant over the period 1992 to 2001 to test for impacts of teamwork and performance-related pay on productivity, accidents, and absence rates. They find that teamwork and performance pay provide incentives to workers to increase quantity at the expense of quality and to run the machines for long hours instead of spending time on maintenance. Absenteeism increases when a combination of teamwork and performance pay is applied to production units that previously had neither. Results suggest that teamwork and performance pay can create hidden costs for manufacturers and do not necessarily increase worker productivity.

[T] he development of an empirically grounded economic theory of incentives depends on research that combines the use of detailed knowledge of the organizational context, a carefully developed model that is appropriate to the context, and rich data drawn from within the organization under study. The search for research settings with these key ingredients will . . . shape the continued development of organizational economics.

Gaynor, Rebitzer, and Taylor (2001: 31)

$\mathrm{H}$

uman resource management practices have changed radically over the past 20 years. Assembly line production organized hierarchically with well-defined line management in a top-down structure has given way to semiautonomous teams in which workers solve problems in groups and sometimes even set their own production targets (Bloom and van Reenen

*Bernd J. Frick is Professor in the Department of Management, University of Paderborn, Germany, and Director of Research at the Institute for Labor and Personnel Economics, AutoUni, Volkswagen AG, Wolfsburg, Germany. Ute Goetzen is Professor and Head of the Institute for Labor and Personnel Economics, AutoUni, Volkswagen AG, Wolfsburg, Germany. Robert Simmons is Professor in the Department of Economics, The Management School, Lancaster University, UK.

We thank the Hans Boeckler Foundation in Duesseldorf for generously funding this project, and the workers and managers of "Company X" for answering our questions. The data we use are proprietary and cannot be made available to other researchers. We will, however, provide a detailed description of the data sets and additional econometric analyses upon request; contact bernd.frick@notes.upb.de, ute.goet zen@volkswagen.de, or r.simmons@lancaster.ac.uk. We are grateful to ILRReview editors Tove Hammer and Lawrence Kahn, as well as two anonymous referees, for their helpful and constructive comments and suggestions.

\footnotetext{
ILRReview, 66(1), January 2013. (c) by Cornell University. Print 0019-7939/Online 2162-271X/00/6601 \$05.00
} 
2007). Innovations in human resource management are claimed to have been at least partly responsible for increased worker productivity in both the United States and Western Europe (Lawler, Mohrman, and Benson 2001; Black and Lynch 2004). Two particular innovations that we consider in this article are growth in use of semiautonomous teams, in a context of assembly line production, and use of bonuses for team performance (performancerelated pay).

We have disaggregated data on productivity, accidents, and absence rates from a large German steel company. Our focus on finely tuned data from within a large company enables us to analyze key variables with a precision that would be lacking in broader establishment-based surveys. As such our empirical analysis sits in the genre of nano-econometrics or "insider" econometrics, which has grown in personnel economics following the seminal work on steel plants in the United States by Ichniowski, Shaw, and Prennushi (1997) (see Lazear and Shaw 2007; Ichniowski and Shaw 2009; Shaw 2009; and Bloom and Van Reenen 2010 for surveys of the literature). This approach emphasizes rigorous econometric analysis of panel data generated within one company or a few companies. An important feature of this empirical work has been the revelation that groups of human resource management policies can raise productivity in steel plants by more than is possible from isolated policies. Thus, human resource management policies can deliver important complementarities in their effects on worker productivity. In our study, we focus on the ability of a combination of semiautonomous teamwork and group performance-related pay to raise productivity in a large German steel company. We also assess some hidden costs of human resource management policies, in the form of work accidents and absenteeism.

\section{Literature Review}

A substantial literature focusing on the impact of high-performance work practices on company performance has been published. ${ }^{1}$ For reasons discussed below we focus on performance-related pay (see Table A.1 in the Appendix) ${ }^{2}$ and on (semiautonomous) teams (see Table A.2). ${ }^{3}$ It appears that, first, the introduction not only of an individual pay-for-performance system but also of team bonuses increases worker productivity in various contexts (blue-collar workers, sales people, medical doctors) and, second, that the implementation of semiautonomous teams is also associated with statistically significant and economically relevant increases in either productivity or profitability. While the evidence on the separate effect of these two instruments seems to be convincing, effects are less clear when considering "bundles" of human resource management practices, among which

\footnotetext{
${ }^{1}$ For summaries of the early literature see Huselid and Becker (1998), Ichniowski and Shaw (2003a), and Ichniowski et al. (1996).

${ }^{2}$ Glassop (2002) provides an overview of the literature from a sociological perspective.

${ }^{3}$ For an overview see Gibbons (1998, 2005), Prendergast (1996, 1998), and Jirjahn (2002).
} 
teamwork and bonus pay are particularly important. Summarizing the available evidence on the impact of innovative work practices on organizational performance, it appears that as expected-but irrespective of the concrete performance measures employed and the peculiar characteristics of the data sets used-specific work practices increase productivity, employee motivation, and/or profits mainly in the context of other specific practices. Unfortunately, however, little, if any, theoretical guidance is provided on how these measures interact. This, in turn, leads many researchers to search for combinations of practices that affect performance significantly in their data sets, but whose effects are idiosyncratic to that data and cannot be demonstrated with data from other settings. Moreover, the possibility that firms already performing well have a greater probability to adopt "high performance work practices"-either because they are able to bear the implementation costs or because they want to share rents with their employees-implies that the positive effect of innovative work practices on performance may not be causal but may simply reflect firm heterogeneity (Cappelli and Neumark 2001). Not surprisingly, therefore, seemingly robust cross-sectional relationships become small or even insignificant when panel data is used to account for unmeasured firm heterogeneity. ${ }^{4}$ Firms that adopt innovative work practices early are likely to do so because these practices are especially useful for them while those who adopt them later either decided to postpone their implementation because the practices have less value for them or because the implementation costs are likely to decrease over time. ${ }^{5}$

Finally, the discussion so far has not yet resulted in a consensus on the combination of measures that have to be implemented to build a highperformance work system. Our reading of the literature suggests that (semiautonomous) teams, on the one hand, and performance-related pay, on the other hand, are among the most important ingredients of any of the bundles for which impact on firm performance is being analyzed in the literature. Admittedly, other human resource management practices have been studied in some detail too, but papers looking at the impact of (semiautonomous) teams and/or performance-related pay on either individual or firm productivity clearly dominate the literature. This does not imply, however, that other instruments such as safety regulations, information sharing, and feedback provision are unimportant. Given the emphasis that Jones, Kalmi, and Kauhanen (2010b) in their empirical analysis, Milgrom and Roberts (1995) in their theoretical exposition, and Lazear and Gibbs (2009) in their textbook place on the particular role of teams and bonus pay though, we will in our study concentrate on the separate as well as the joint impact of these two practices on the performance of individual production units in a

\footnotetext{
${ }^{4}$ Another reason cross-sectional relationships may become insignificant in panel data is measurement error.

${ }^{5}$ Another interesting strand of the literature looks at the impact of "soft" human resource management practices, such as development talks, participation, and feedback on worker productivity, and finds significantly positive effects, inter alia, for firms in the retail industry (see, e.g., Jones, Kalmi and Kauhanen 2006, 2010a).
} 
large German steel company while simultaneously controlling for the (potential) influence of a large number of additional-yet (presumably) less important-measures.

A small number of studies have adopted a similar approach to the one we have chosen. In a truly seminal-but still not fully acknowledged-paper, Wagner, Rubin, and Callahan (1988) analyzed the impact of the introduction of nonmanagerial incentive pay in an iron foundry over an extended period of time (114 months between February 1975 and July 1984) on monthly productivity, labor costs, and grievance procedures. They find that the introduction of a group bonus increases average daily tonnage while labor costs declined and the number of grievance procedures remained constant; however, the impact of other changes in supervisory personnel and shop floor practices was not explicitly tested for. ${ }^{6}$ Hamilton, Nickerson, and Owan (2003) study the implementation of teamwork in a garment manufacturing facility over a period of three years for which they have weekly information on 25 different teams. They find that, contrary to expectations, an individual worker's productivity increases $14 \%$ after joining a semiautonomous team. Moreover, high-productivity workers do not reduce their effort levels when joining a team, while particularly low-productivity workers significantly increase their effort levels. In the firm under study, the implementation of semiautonomous teams was not accompanied by the simultaneous or subsequent introduction of a group bonus. Finally, Jones, Kalmi, and Kauhanen (2010b) use weekly records for four production lines in a Finnish food-processing plant during the period 1999 to 2005 to study the impact of semiautonomous teams, company-wide profit sharing, and a group system of performance-related pay on line productivity. They find that the effects vary considerably, first, across lines and, second, depending on the specific combination of human resource management practices, suggesting the importance of complementarities.

\section{Company Description}

Company $\mathrm{X}$ is a large steel-producing company located in the federal state of North Rhine-Westphalia in Germany. In September 2001 the company had about 2,500 employees of whom 1,700 were working in the production of autobody sheet steel as well as steel sheets designed for the production of cans for the soft-drink industry. About $60 \%$ of the annual production (900,000 tons per year) was exported. About half of the export went to European countries. Turnover in 2001 was $€ 770$ million.

During the 1970s, Company X was one of the best performing firms in its sector with profits far above the industry average. During the 1980s, profits

\footnotetext{
${ }^{6}$ Moreover, Schuster (1983), Kaufman (1992) as well as Arthur and Aiman-Smith (2001) find that gainsharing (a team bonus covering the whole workforce of a particular company) has a significantly positive impact on productivity, employment, and employee suggestions. This effect, however, seems to vary considerably over time.
} 
declined dramatically due to a number of mergers, privatizations of formerly state-owned steel companies in Western European countries, the emergence of new competitors especially from Asia, and rising costs for energy as well as for wages.

In 1993 the company lost money for the first time in its history. Management reacted with a massive layoff (1,000 employees, among them 100 white-collar employees who were fired) and changed its policies fundamentally:

1994: re-organization starts in the production units; requirement to meet particular production targets/goals,

1995: re-organization starts in administration,

1996: reduction of absenteeism is declared a "high priority" target, integration of formerly "independent" maintenance workers in shift teams,

1997: stepwise introduction of new bonus system, training in workplace safety and accident prevention, bonus system for reduced absenteeism, monitored requirement to wear hard hats,

1998: introduction of appraisal interviews, introduction of extended employee suggestion system,

1999: stepwise introduction of semiautonomous teams in production for the purpose of problem-solving activities, flexible job assignments, and quality management, and

2000: safety staff explicitly authorized to issue directives toward employees for violations of safety regulations.

According to the company's top management these changes resulted in a $34 \%$ increase in gross output and a $40 \%$ increase in productivity (tons produced per hour) in 2001 as compared to 1993. Since 2002 the company is highly profitable again.

The teams whose performance we study consist of approximately 80 to 300 members who are very homogenous with regard to their qualifications but often heterogeneous with regard to their age and/or their tenure. ${ }^{7} \mathrm{Be}-$ cause voluntary employee turnover in Company $\mathrm{X}$ is close to zero-the firm pays about 15 to $20 \%$ more than what workers could earn elsewhere in the mainly rural area where the firm is located ${ }^{8}$ - mutual monitoring plays an important role in the daily interaction of the production workers; "uncooperative" workers are likely to be punished by their peers (Kandel and Lazear 1992; Knez and Simester 2001). At the same time, however, the high degree of "cohesiveness" of the individual teams creates the conditions

\footnotetext{
${ }^{7}$ The teams are identical to what we call "production units." Each team consists of up to five different "shift groups" (between four and five different shifts are required for continuous production under the 35-hour work week stipulated by the collective bargaining agreement in the steel industry); the size of the semiautonomous teams working in close collaboration varies between 20 and 60 people.

${ }^{8}$ Traditionally, the collective bargaining agreements in the metal and steel industries stipulate hourly wage rates that are considerably higher than in most other industries. Therefore, the majority of workers in Company $\mathrm{X}$ are interested in retaining their jobs until they reach retirement age.
} 
Table 1. Work Accidents in Germany per 1,000 Workers, 1993-2001

\begin{tabular}{cccc}
\hline Year & All sectors & Metal industry & Firm X \\
\hline 1993 & 52 & 70 & 25 \\
1994 & 51 & 69 & 36 \\
1995 & 48 & 67 & 61 \\
1996 & 43 & 58 & 24 \\
1997 & 42 & 58 & 22 \\
1998 & 42 & 57 & 13 \\
1999 & 41 & 58 & 11 \\
2000 & 40 & 55 & 9 \\
2001 & 39 & 52 & 10 \\
\hline
\end{tabular}

Sources: Bundesministerium für Arbeit und Sozialordnung (2001: 143-45); own calculations.

Note: Accidents that have to be reported per 1,000 fulltime employees.

Table 2. Absenteeism in Germany, 1996-2001

\begin{tabular}{lccc}
\hline Year & All sectors & Metal industry & Firm X \\
\hline 1996 & 4.8 & 5.4 & 3.4 \\
1997 & 4.2 & 5.2 & 3.3 \\
1998 & 4.1 & 5.2 & 3.5 \\
1999 & 4.3 & 5.6 & 3.3 \\
2000 & 4.2 & 5.5 & 3.3 \\
2001 & 4.2 & 5.5 & 3.2 \\
\hline
\end{tabular}

Sources: Küsgens, Vetter, and Yoldas (2001: 264, 402); own calculations.

Note: Hours of absence as percentage of potential working hours.

under which "collusive behavior," such as "voluntary" absenteeism, is likely to occur (see, e.g., the seminal studies by Roy 1952, 1954).

The number of work accidents in Company $\mathrm{X}$ was far lower than in the metal industry as a whole (10 accidents per 1,000 full-time employees compared with 52 in 2001, see Table 1) and the absence rate was also considerably lower (3.2\% compared with $5.5 \%$ in 2001 , see Table 2 ). These figures are surprising insofar as

1) absence rates increase with firm size (Barmby and Stephan 2000; Heywood and Jirjahn 2004) and Company $\mathrm{X}$ is a rather large firm, and

2) workplace accidents decrease with firm size, which explains the lower number of accidents in Company X. At the same time, however, the number of accidents is much lower than in other firms in the industry suggesting that worker and supervisor training as well as the company's investments in workplace safety seem to pay off.

Workers receive a flat hourly rate supplemented, for some production units, by a bonus payment related to production unit output. A "cap" is imposed 
on the bonuses to be obtained by the individual teams. Bonus payments cannot exceed a threshold level of $140 \%$ of regular hourly wages multiplied by average monthly working hours. Also, bonuses accrue to the team, not the individual. We should stress that the company explicitly wanted to reduce absenteeism and implemented bonus payments precisely as an intended incentive to reduce absences. A "present at work" bonus was installed alongside the bonus for production performance.

Note that management-labor relations have been rather peaceful in Company X: The works council maintains a cooperative relationship with top management, management consults the works council even on issues for which this is not stipulated by the Codetermination Act to gain approval or active support for its decisions, and trade union influence is limited (although most works councillors are members of IG Metall, the largest metal workers' union in Europe).

\section{Theoretical Considerations}

Since the steel company that we are analyzing has assembly line production, the whole line could be thought of as a team. The organization of work around small- to medium-sized teams is best considered as an attempt to raise worker productivity by capturing the benefits of specialization and skill complementarities within groups. These benefits can be reinforced by learning spillovers and knowledge transfer as team members gain experience that can be shared within the group. For these effects to be realized, team size should be sufficiently small so that workers are aware of each others' skills and performances, and team members should be located in close proximity at the workplace (Neilson 2007).

A series of empirical studies documents the benefits of teamwork in terms of enhanced worker productivity (see Lazear and Shaw 2007 for a survey). Thus, teams are found to raise productivity through worker complementarity in production of clothing (Hamilton, Nickerson, and Owan 2003), to raise communication levels in steel mills (Ichniowski and Shaw $2003 \mathrm{~b}$ ), and to facilitate solutions of complex problems, again in steel mills (Boning, Ichniowski, and Shaw 2007). In their seminal study of U.S. steel mills, Ichniowski, Shaw, and Prennushi (1997) found that early on in the application of new human resource management practices in the U.S. steel industry, such policies raised worker productivity and, crucially, that the marginal benefit of each practice was increasing in the adoption of other practices. More recently, Boning et al. (2007) were able to distinguish between gross output and output net of scrap in a panel study of several U.S. steel plants. They found that combinations of human resource management policies were generally able to raise output net of scrap, that is, quality-adjusted output.

Team production does not necessarily imply the use of incentive pay, but bonuses for team performance are widely used in modern manufacturing 
companies. Such bonuses enable workers and firms to share rents; bonuses also help alleviate worker concerns over inequity in pay in firms and promote perceptions of fairness, which in turn raise worker satisfaction and morale (Petrescu and Simmons 2008). These features could in principle translate into increased team productivity.

The potential problems for team incentives in the form of performancerelated pay are well-documented (Neilson 2007). First, individual workers bear the cost (disutility) of their own effort but all team members benefit through performance-related pay. Team incentives tend to dilute the salary gains from work and could lead to minimal amounts of team effort as a result. Second, a free-rider problem can occur in teams. Individuals who offer low levels of effort get the same rewards as colleagues who perform high levels of effort. Third, much depends on finding a measure of team performance that workers and firms can agree on. For workers, this means a set of operationally feasible production targets that can trigger bonuses; for firms, targets should be appropriate to the broader profit goal of the organization as a whole. Production targets should also not be too soft, so that credible incentives can be established.

In contrast, decentralizing decision-making to teams might generate positive effects on productivity (as well as on behavioral aspects) by increasing employee discretion, which allows more efficient use of private information; by increasing employee effort and improving their attitudes toward work; and by encouraging team members to learn from one another and generate new knowledge (for a summary of the relevant literature see, e.g., Jones, Kalmi, and Kauhanen 2010b). Effective decentralization of decision-making often requires the adoption of complementary team incentives, because the "coupling of financial incentives with teamwork may provide the right incentives for employees both to engage in peer monitoring and to refrain from opportunistic use of increased employee discretion" (Jones et al. 2010b: 612). Thus, it is precisely the combination of team incentives and decentralized decision-making in the form of semiautonomous teams that can be thought to solve the problems that typically arise when close cooperation between teammates is likely to increase productivity and when, at the same time, peer monitoring is required to avoid "free-riding" by utilitymaximizing individuals.

Our empirical analysis seeks to identify some potentially hidden costs of team production and performance-related pay. Taken singly or jointly, these human resource policies could lead to an excessive focus by workers on total output that might be rewarded by incentive pay. Quality of output and care over maintenance may be sacrificed as workers perform excessive effort in a drive to meet production targets that trigger performance bonuses. If these bonuses are not modified to control for quality of output then teamwork and performance-related pay could result in lower rather than higher team productivity. Also, if team members work excessively hard without sufficient care then increased work accidents could follow. 


\section{Model, Estimation Methods, and Data}

We define ABSENCE RATE as the proportion of potential worker-hours in a production unit declared by the firm as absences in a given month. This is modeled by:

$$
\begin{gathered}
\text { ABSENCE RATE }=\beta_{0}+\beta_{1} \text { PLD }+\beta_{2} \text { MONTH }+\beta_{3} \text { YEAR } \\
+\beta_{4} \text { PERSONNEL MANAGER }+\beta_{5} \text { TECHNICAL MANAGER } \\
+\beta_{6} \text { SHIFT }+\beta_{7} \text { HRM }+\beta_{8} \text { TENURE }+\beta_{9} \text { PERFORMANCE } \\
P A Y+\beta_{10} \text { TEAMWORK }+\beta_{11} \text { TEAMWORK } * \text { PERFORMANCE } \\
\text { PAY }+\varepsilon
\end{gathered}
$$

where

ABSENCE RATE is the proportion of potential worker-hours in a production unit declared by the firm as absences in a given month;

$P L D$ is a vector of production line dummies;

MONTH is a vector of month dummies;

YEAR is a vector of year dummies;

PERSONNEL MANAGER is a vector of dummy variables denoting the identities of personnel managers directly responsible for the pay and employment conditions of the units of workers $;{ }^{9}$

TECHNICAL MANAGER is a vector of dummy variables denoting the identities of technical managers responsible for the production operations of the shifts to which the units of workers belong;

SHIFT is a vector of five shift dummies;

$\boldsymbol{H R M}$ is a vector of variables denoting combinations of human resource management practices, derived from factor analysis; ${ }^{10}$

TENURE is the average length of tenure with the firm of each production unit; we predict that units with longer-lasting employment relations with the firm will have greater experience and will wish to sustain mutually beneficial employment relationships with the firm, resulting in lower absence rates;

\footnotetext{
${ }^{9}$ Since personnel and technical managers rotate across production units, teams experience changes in their supervisory staff from time to time. We take this into account by controlling for the identities of the five personnel managers and the five technical managers in charge of the 25 production units.

${ }^{10}$ The results can be obtained from the authors on request. The number of dummy variables included in this first factor analysis was 15 , resulting in a varimax rotated factor matrix consisting of three components with eigenvalues $>1$. These factors can be described as follows: (1) action programs to increase workplace safety (representing 8 different variables: publication of first safety handbook; target: zero accidents; obligation to wear hard hats; general training of safety staff; suggestion scheme: accident reduction; target: absenteeism; implementation of absence bonus; target: accident prevention); (2) information and directives (representing 5 different variables: publication of second safety handbook; target: absence days; special training of safety staff; authorization of safety staff to issue directives; safety training of new employees); and (3) worker training to increase safety (representing 2 different variables for safety trainings of special groups of workers). About $76 \%$ of the variance can be explained by the three factors.
} 
Table 3. Work Accidents and Absence Rates in Firm X, 1993-2001

\begin{tabular}{lcccc}
\hline Year & $\begin{array}{c}\text { Work accidents per } \\
\text { 1,000 full-time employees }\end{array}$ & $\begin{array}{c}\text { Number of working days lost } \\
\text { due to accidents, per employee }\end{array}$ & Absence rate \\
\hline 1993 & $25.2(157.1)$ & $0.51(1.91)$ & - \\
1994 & $36.2(186.8)$ & $1.27(5.14)$ & - \\
1995 & $61.3(240.1)$ & $2.84(12.80)$ & - \\
1996 & $23.6(151.9)$ & $1.73(10.12)$ & $3.39(3.12)$ \\
1997 & $22.0(157.2)$ & $1.30(6.97)$ & $3.33(2.96)$ \\
1998 & $12.6(111.5)$ & $0.91(6.30)$ & $3.46(3.49)$ \\
1999 & $11.0(104.4)$ & $0.85(8.45)$ & $3.32(3.51)$ \\
2000 & $9.4(96.7)$ & $0.42(4.01)$ & $3.29(3.38)$ \\
2001 & $10.5(102.0)$ & $0.40(3.74)$ & $3.22(3.22)$ \\
\hline
\end{tabular}

Note: Values indicate mean (standard deviation).

Table 4. Distribution of Monthly Observations with/without Teamwork and/or Performance Pay

\begin{tabular}{lccc}
\hline Variable & $\begin{array}{r}\text { Productivity } \\
\text { information } \\
(\%)\end{array}$ & $\begin{array}{c}\text { Absence } \\
\text { rates } \\
(\%)\end{array}$ & $\begin{array}{c}\text { Accident } \\
\text { figures } \\
(\%)\end{array}$ \\
\hline Neither teamwork nor performance pay & 68.8 & 52.1 & 70.6 \\
Performance pay only & 19.6 & 25.0 & 15.7 \\
Teamwork only & 1.5 & 6.5 & 3.9 \\
Teamwork with performance pay & 10.1 & 16.4 & 9.9 \\
$\mathrm{~N}$ & 2,700 & 3,180 & 5,088 \\
\hline
\end{tabular}

PERFORMANCE PAY is a dummy variable set equal to 1 if a production unit receives some part of their pay as a performance-related component and no teamwork is involved (note that our human resource policy dummy variables are deliberately designed to be mutually exclusive);

TEAMWORK is a dummy variable set equal to 1 if members of a production unit work jointly as a team and no performance pay is involved;

TEAMWORK ${ }^{*}$ ERFORMANCE $P A Y$ is an interactive dummy variable set equal to 1 if members of a production unit work as a team and receive some performance-related component to their pay; and

$\varepsilon$ is an i.i.d stochastic term.

To investigate the effects of teamwork and performance pay on absenteeism, we model ABSENCE RATE as a continuous variable as shown in Equation (1). Since our dependent variable is a rate that is bounded between 0 and 1, we need to estimate a fractional response model along the lines proposed by Papke and Wooldridge (1996, 2008). Papke and Wooldridge apply fractional response model estimation to employee participation rates in pension plans (1996) and school test pass rates (2008). Our dependent variable is similar. Oberhofer and Pfaffermayr (2009) show that fractional response models can be estimated by general linearized models. Specifically, 
Figure 1. The "Timing" of the Introduction of Teamwork and Performance Pay

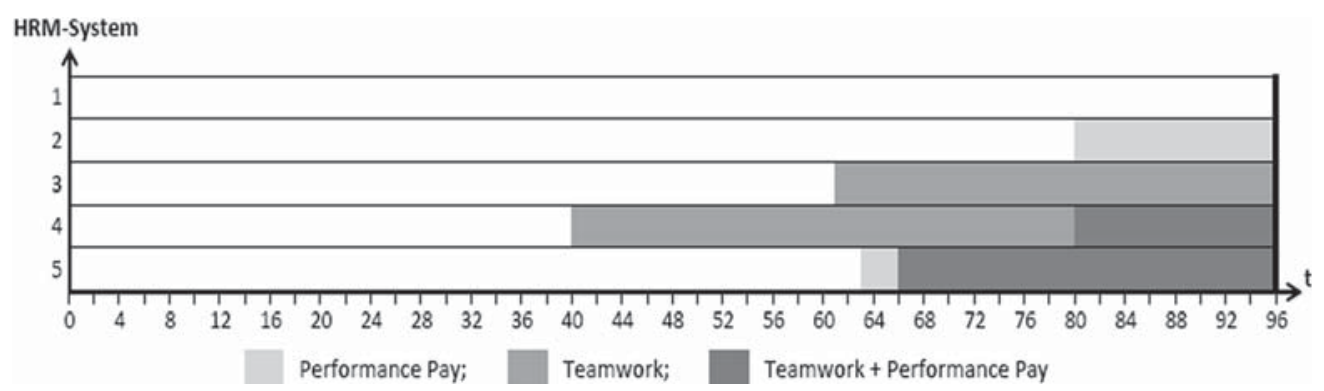

the results from the fractional response model of Papke and Wooldridge (1996) can be replicated using the glm command in Stata. We apply this approach to our absence rate variable. Absence data are available on a unit/ shift basis but only from October 1996, and we have 60 monthly observations of absence rates per unit/shift, giving a potential number of 3,180. Missing values mean our absence rate data are recorded for 3,001 shift-unit observations. Table 3 offers descriptive data for work accidents and absences.

For production unit-month observations where absences were recorded we find $25.0 \%$ with performance pay only, $16.4 \%$ with teamwork only, and $6.5 \%$ with teamwork and performance pay. Hence, $52.1 \%$ of observations had neither teamwork nor performance pay (see Table 4 for information on the distribution of the four regimes and Figure 1 for an illustration of the distribution of teamwork and performance pay across the units of analysis).

As noted above, to claim bonus pay, production units might perform excessive effort leading to lack of care over safety resulting in greater frequency of accidents. We have two measures of accidents in the firm. ACCIDENTS is number of accidents by production unit and WORKING DAYS LOST is production days lost from accidents. We set up the following model. For numbers of accidents, zeros represent $86 \%$ of observations and OLS estimation would be inappropriate. Days lost due to accidents have discrete values and we categorize these as 0,1 , or 2 days lost, 3 days lost, and 4 or more days lost. We proceed to estimate these categories by fixed effects conditional logit. Fixed effects models do not necessarily deliver consistent estimates in ordered or binary probit models. Chamberlain (1980) proposed a binary response fixed effects logit model in which biases were eliminated. More recent analysis has developed ordered logit models with fixed effects. In particular, we use the Blow-up and Cluster estimator proposed by Baetschmann, Staub, and Winkelmann (2011) and applied with Stata code by Dickerson, Hole, and Munford (2011). This estimator adjusts standard errors for clustering by group and does not suffer from the potential problems of the Chamberlain estimator associated with some cutoffs in the ordering leading to small sample sizes. This is a potential problem in our case as accidents have a skewed distribution. We also estimated an alternative count data model, fixed effects zero inflated negative binomial regression, and this gave similar results to fixed effects ordered logit. Our model is 


$$
\begin{gathered}
\text { Pr }(\text { ACCIDENTS or }(\text { WORKING DAYS LOST }))=\beta_{12}+\beta_{13} \text { PLD } \\
+\beta_{14} \text { YEAR }+\beta_{15} \text { PERSONNEL MANAGER }+\beta_{16} \text { TECHNICAL } \\
\text { MANAGER }+\beta_{17} \text { SHIFT }+\beta_{18} \text { HRM }+\beta_{19} \text { TENURE }+\beta_{20} \text { PERFORMANCE } \\
\text { PAY }+\beta_{21} \text { TEAMWORK }+\beta_{22} \text { TEAMWORK } * \text { PERFORMANCE } \\
\text { PAY }+ \text { production unit fixed effects }+\varepsilon
\end{gathered}
$$

We have 96 monthly observations for accidents by unit/shift over the period October 1993 to September 2001 giving a potential number of observations of 5,088. Dropped from the estimation were 403 observations because there was no variation over time in the outcome variable for some groups. This leaves 4,685 observations for estimation.

Next, we assess the impacts of performance pay and teamwork on production line performance. This is measured by realized output, $R O$, of each of the 25 production units working in the company. Our data allow us to distinguish output of sufficient quality to be available for sale, adjusted output denoted by $A O$. This is quality-adjusted output, which is output net of waste scrap. The waste scrap cannot be sold but can be recycled back into further production. Further measures of production unit performance are $R T$, which is running time of the production line and $A R T$, which is adjusted running time, net of time taken for unscheduled maintenance of the line. We estimate the following fixed effects models:

$$
\begin{gathered}
\text { RO }(\text { or AO or RT or ART })=\beta_{23}+\beta_{24} \text { PERSONNEL } \\
\text { MANAGER }+\beta_{25} \text { TECHNICAL MANAGER }+\beta_{26} \text { MONTH } \\
+\beta_{27} \text { YEAR }+\beta_{28} \text { ORG CHANGE }+\beta_{29} \text { PERFORMANCE PAY } \\
+\beta_{30} \text { TEAMWORK }+\beta_{31} \text { TEAMWORK } * \text { PERFORMANCE PAY }+\varepsilon
\end{gathered}
$$

where $\boldsymbol{O R G} \boldsymbol{C H A N G E}$ is a vector of variables denoting technical and organizational changes, derived from factor analysis. ${ }^{11,12}$

\footnotetext{
${ }^{11}$ The results are also available on request. The number of dummy variables included in this second factor analysis was 23, resulting in a varimax rotated factor matrix consisting of 6 components with eigenvalues $>1$. These factors can be described as follows: (1) training and reorganization measures (representing 5 different human resource management practices: integration of shift coordinators into shift teams; extended training of production workers; integration of mechanics and electricians into shift teams; action program to increase output; and introduction of additional quality measures); (2) organizational decentralization (representing 7 different instruments: cross-linking of production teams; introduction of autonomous maintenance; introduction of performance appraisal of shift leaders; decentralization of suggestion scheme; action program to increase capacity utilization; integration of repair services into shift teams; and introduction of fifth shift); (3) training and evaluation (representing 5 different instruments: integration of locksmiths into shift teams; extended quality training of production workers; training of production workers in electrical engineering; introduction of "shift talks"; and presentation of pilot project on capacity utilization); (4) evaluation and quality management (representing 2 different measures: introduction of "round table" for shift leaders; start of quality training); (5) new performance measures (representing 2 different instruments: introduction of service technicians; change in performance calculations); and (6) reallocation of technical staff (representing 2 different measures: reallocation of coordinating staff; separation of hood-type furnaces). About $77 \%$ of the variance can be explained by the 6 factors.

12 The reason we had to replace HRM (the vector of variables denoting combinations of human resource management practices derived from factor analysis) in models 1 and 2 by ORG CHANGE in
} 
For productivity measures,${ }^{13}$ we have data from 25 different production units. Productivity is recorded only at the level of the production unit; no further disaggregation is possible. We have 108 monthly observations over the period October 1992 to September 2001, giving a maximum of 2,700 observations. Some missing values reduce the sample sizes to 2,673 for actual output, 2,676 for adjusted output and running time, and 2,006 for adjusted running time. Out of 25 production units, 13 delivered data on accidents (numbers and working days lost). Estimation of Equation (3) allows us to test for impacts of performance-related pay and teamwork on output and running time. Although we might predict that firms introduce teamwork and performance-related pay precisely in order to increase these measures, evidence is far from unanimous in revealing beneficial effects of these mechanisms.

\section{Results}

Coefficients of focus variables are reported in Table 5. By themselves, teamwork and performance pay each have significant negative effects on absence rates. But teamwork combines with performance pay to significantly raise absence rates. To assess the combined effects of teamwork and performance pay we use the separate teamwork and performance pay dummy variables plus their interaction term as follows. ${ }^{14}$ We can rewrite Equation (1) as:

$$
\begin{gathered}
\text { ABSENCE RATE }=b_{0}+b_{1} \text { PERFORMANCE PAY } \\
+b_{2} \text { TEAMWORK }+b_{3} \text { TEAMWORK * PERFORMANCE } \\
\text { PAY }+c^{\prime} \boldsymbol{Z} \text { where } \boldsymbol{Z} \text { is a vector of controls. }
\end{gathered}
$$

Recall that the performance pay, teamwork, and interaction variables are defined to be mutually exclusive. Then $b_{1}$ is the effect of performance pay without teamwork, $b_{2}$ is the effect of teamwork without performance pay, and $b_{3}$ is the effect of having both teamwork and performance pay relative to having neither. Moreover, $\left(b_{3}-b_{1}\right)$ is the effect of adding teamwork to a unit that already had performance pay and $\left(b_{3}-b_{2}\right)$ is the effect of adding performance pay to a unit that already had teamwork. The significance of these last two effects can be evaluated using Wald tests.

model 3 is that the two data sets the company made available to us include different sets of (potential) determinants of absenteeism and accidents, on the one hand, and productivity and downtime, on the other hand. We admit, however, that either of these variables could affect each of our performance measures.

${ }^{13}$ Strictly speaking, we cannot calculate the productivity of the individual units because we can neither control for the number of workers nor for the number of hours used to generate the observed output and the observed running time. Given the information we have received from workers during our plant visits, however, we assume that differences in output and running time are due to time-invariant differences in team size and composition. Thus, we assume that the production unit fixed effects capture most of the differences in inputs.

${ }^{14}$ We are grateful to ILRReview editor Lawrence Kahn for suggesting this procedure. 
Table 5. Impact of Teamwork and Performance Pay on Absence Rates

\begin{tabular}{lc}
\hline Variable & GLM coefficient \\
\hline Average age of workers & -0.017 \\
& $(-2.64)$ \\
Performance pay only & -0.108 \\
& $(-2.17)$ \\
Teamwork only & -0.236 \\
& $(-2.32)$ \\
Teamwork with performance pay & 0.194 \\
& $(2.72)$ \\
Factor 1: Action programs & -0.205 \\
& $(-1.93)$ \\
Factor 2: Information and directives & -0.290 \\
& $(-3.02)$ \\
Factor 3: Safety training & -0.002 \\
& $(-0.10)$ \\
$\mathrm{N}$ & 3,001 \\
\hline
\end{tabular}

Notes: Dependent variable is absence rate measured as total hours absent as proportion of maximum working hours by production unit. Estimates are from GLM regression with robust standard errors, with dummy variables for month and year, and with hours of work to account for the size of the production units; $z$-values in parentheses.

Table 5 reveals that, on their own, teamwork and performance pay lead to reduced absence rates. Wald tests of the restriction that the difference of the interaction term coefficient and an individual human resource policy coefficient is equal to zero clearly reject the null ( $p$ values of 0.00 in each case). Hence, we conclude that adding teamwork to a unit that already has performance pay and adding performance pay to a unit that already has teamwork does result in a statistically significant increase in absence rate. Furthermore, adding performance pay and teamwork to a unit that has neither is shown to have a significant positive effect on absence rate. The size of this effect can be evaluated by computing predicted mean absence rates, using Stata's margins command. The baseline predicted absence rate with no teamwork and no performance pay system is $3.32 \%$. When teamwork and performance pay are introduced together the predicted absence rate rises to $4.01 \%$.

Drawing from a sample of German manufacturing firms, Heywood and Jirjahn (2004) observed that firms using teamwork had lower absence rates. This was attributed to larger costs of absence with teamwork and increased incentives to use monitoring to deter absence and reduce costs. Our results are consistent with Heywood and Jirjahn to some extent since we find that our firm is predicted to experience reduced absenteeism when it introduces teamwork without performance pay.

Our finding of an adverse effect on absenteeism from a combination of human resource policies is a new result to the literature on the effects of such practices on organizational performance. We suggest a hidden cost to 
human resource management practices occurs. Teamwork and performance pay appear to promote shirking in the form of absenteeism, compared to a situation in which neither policy is in place. Of course, it is possible that teams can generate spare effort so as to be able to cover absence of teammates and continue the production process without undue disruption. Then shirking and absenteeism can co-exist with higher productivity. Our analysis refers to production units across a particular firm, and there is no reason to expect that results from a panel of firms should correspond to results from a panel of production units within a firm.

One reason for why a combination of performance pay and teamwork leads to increased absenteeism is that, with teamwork, production units can cover for absent colleagues. For example, workers can alternate who takes an unauthorized day of absence each month knowing that colleagues will conceal this from the company. Also, with performance pay, workers have the incentive, as well as the means, to take unauthorized absence as the bonus payment is capped at $140 \% \mathrm{x}$ regular hourly wage $\mathrm{x}$ average monthly working hours. Presence at work, and hence absence rate, is partly a function of the remaining output that is required to reach maximum earnings possible under the bonus cap. It is, therefore, not at all surprising that $75 \%$ of all work accidents happen in the first half of each month (when workers are eagerly trying to meet their production targets) while more than $70 \%$ of all absence days (net of days lost due to work accidents) occur in the second half of the month (when workers anticipate that they will be able to meet these targets).

Perhaps surprisingly, the combined effects of action programs to increase workplace safety, of providing detailed information and issuing directives, as well as from worker safety trainings turn out to be of minor importance only. The coefficient of the second variable is statistically significant while the other two are insignificant. ${ }^{15}$

Table 6 reports estimates of coefficients from a fixed effects ordered logit model of number of accidents and days lost due to accidents. Results in both columns of Table 6 are remarkably similar and consistent. Production units with greater average age of workforce are significantly associated with greater probability of zero days lost through accidents and lower probability of one or more days. This result is consistent with the notion that more experienced production units are more careful, make fewer mistakes, and cause less production disruption through accidents than less experienced units. To some extent, an element of self-selection takes place here in that workers who are perceived to be careless are likely to have been fired, or encouraged to leave, by the company. Moreover, production units that work longer hours are associated with higher probabilities of positive accidents and positive days lost through accidents. The coefficients on teamwork and performance pay, however, are insignificant throughout, whether considered singly or jointly.

\footnotetext{
${ }^{15}$ The implementation of safety programs could have been influenced by a previous change in accident rates. This makes it difficult to reveal an effect of action programs, even in a fixed effects model.
} 
Table 6. Fixed Effects Conditional Logit Coefficients for Probability of Accidents and Days Lost through Accidents

\begin{tabular}{lcc}
\hline Variable & Accidents & Days lost \\
\hline Age & $\mathbf{- 0 . 0 8 0 ( 2 . 4 6 )}$ & $\mathbf{- 0 . 0 7 9}(\mathbf{2 . 4 4 )}$ \\
Hours & $\mathbf{0 . 0 0 0 4 4}(\mathbf{3 . 4 3})$ & $\mathbf{0 . 0 0 0 4 4}(\mathbf{3 . 0 9})$ \\
Performance pay only & $0.161(0.64)$ & $-0.246(0.67)$ \\
Teamwork only & $0.118(0.30)$ & $0.156(0.53)$ \\
Teamwork with performance pay & $0.118(0.30)$ & $0.082(0.24)$ \\
N of outcomes & 4,685 & 4,685 \\
\hline
\end{tabular}

Notes: Dependent variables are probability of number of accidents and probability of days lost. Estimates are coefficients from fixed effects ordered logit regressions with dummy variables for month and year and with working hours to control for the size of the production units and three factors representing a wide range of safety practices $(n=15)$. Estimates are by Blow up and Cluster procedure in Stata 12; $z$-values in parentheses.

Since the firm's contributions to the accident insurance fund are experience-rated and increase nearly exponentially with the number of accidents reported, investing in workplace safety is likely to pay off even in our Company X that reports a below average number of accidents per year.

Therefore, performance pay, with or without teamwork, is not significantly related to an increase in accident-related loss of production. Our proposed rationalization of this effect is that accidents in the Company X steel plant are indeed random. The company has succeeded in avoiding systematic causes of accidents attributable to behavior induced by its human resource management policies and is unable to reduce accidents any further, other than by retaining older workers and keeping work hours below excessive levels.

So far we have found that teamwork combined with performance pay raises absence rates while performance pay, with or without teamwork, does not raise the likelihood of disruption to production because of accidents. We turn, finally, to our productivity models. Descriptive evidence of the effects of teamwork and/or performance pay on productivity of units is provided in the box plots displayed in Figures 2 to 5 .

Column 1 of Table 7 reveals that realized output increases for units that have performance pay (but not teamwork) by about $1.8 \%$ (both output measures are normalized with their respective mean equal to zero). ${ }^{16}$ This effect is reinforced when performance pay is combined with teamwork (plus $3.4 \%$ ). Adding teamwork to a unit that already has performance pay results in significantly greater realized output ( $p$ value of 0.002 from a Wald test).

\footnotetext{
${ }^{16}$ The company did not have an explicit performance appraisal system for its production units. If recent changes in unit productivity led management to adopt teamwork for that unit then we may be estimating a spurious relationship between adoption and post-adoption productivity. If adoption decisions were imposed arbitrarily without a formal review of the unit's performance trend then the adoption of a human resource management practice for a given production unit is more likely to be exogenous with respect to that unit. Informal conversations with company managers lead us to this latter view.
} 
Figure 2. Box Plot of Realized Output by Type of Work Organization

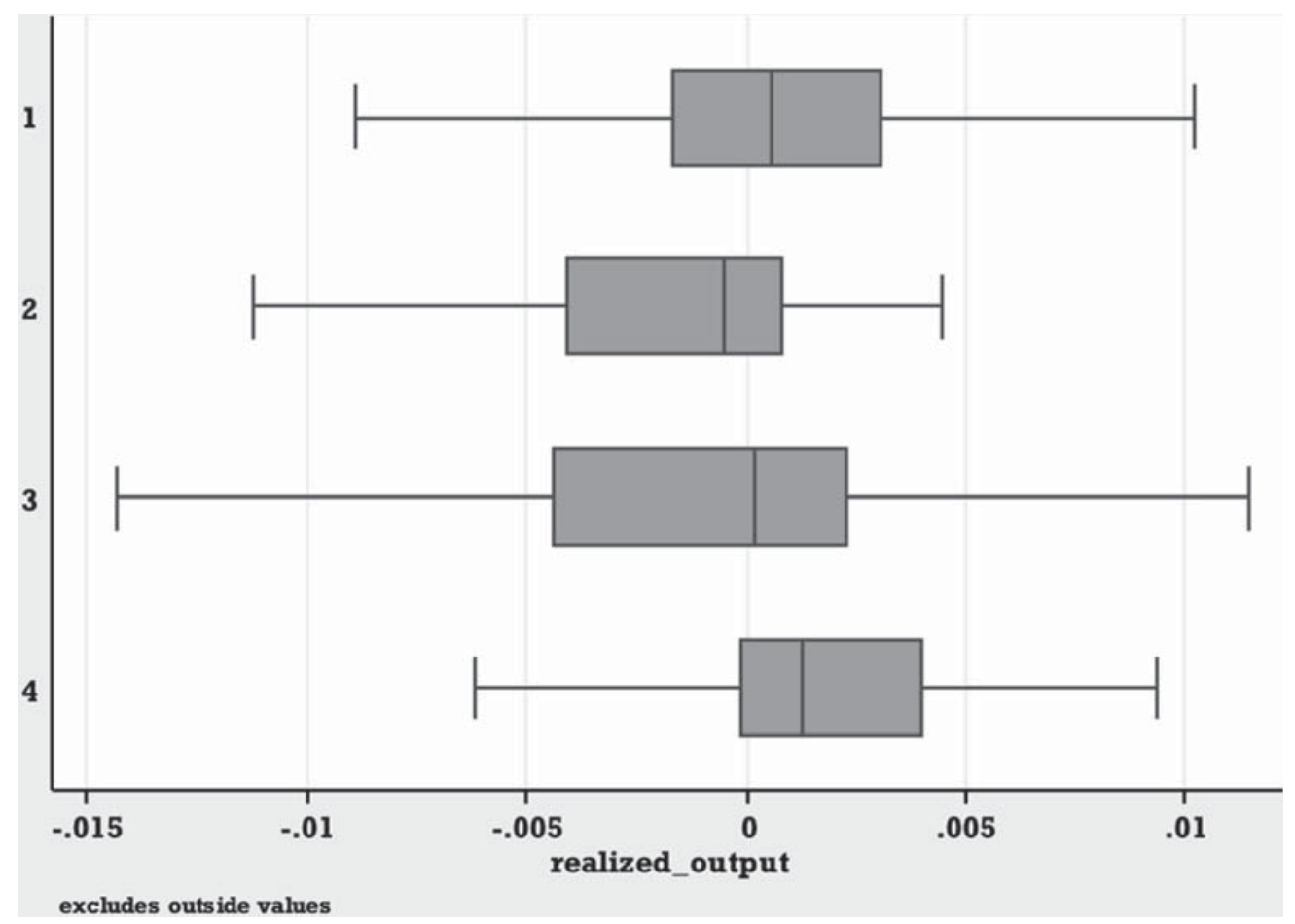

Figure 3. Box Plot of Adjusted Output by Type of Work Organization

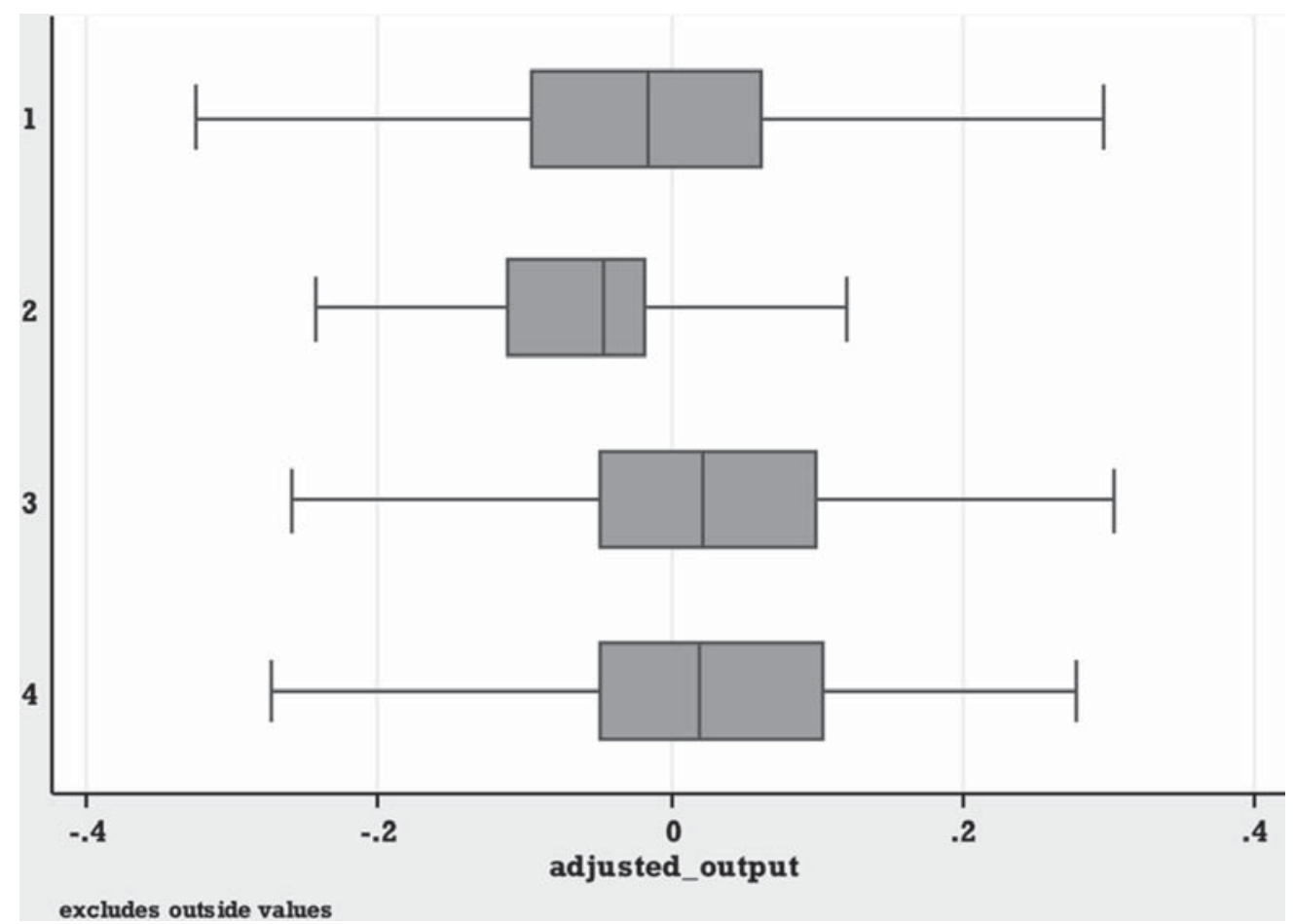


Figure 4. Box Plot of Running Time by Type of Work Organization

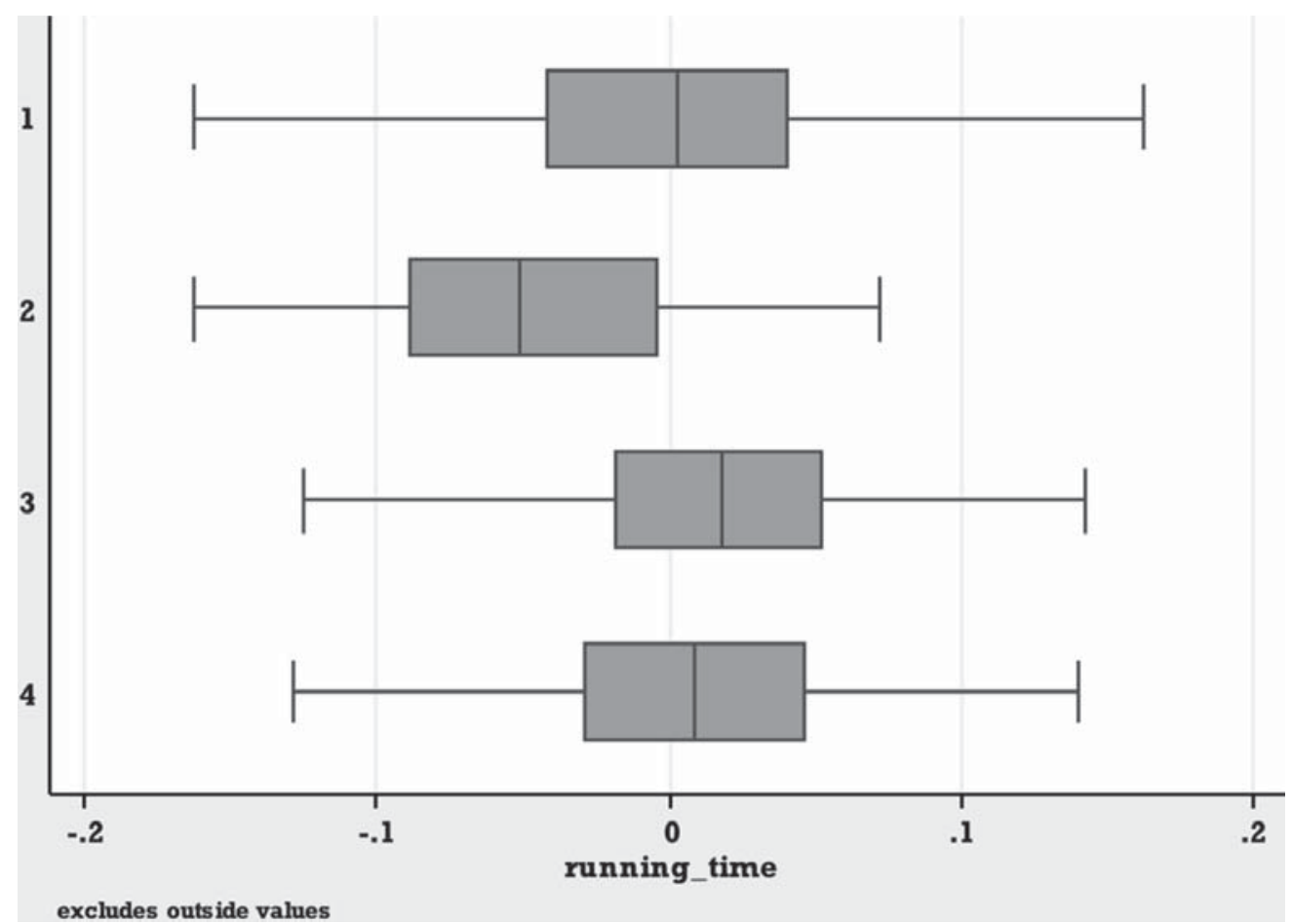

On its own, teamwork has no statistically significant impact on realized output. Adding performance-related pay to a unit that has teamwork delivers significantly higher gross output from production units ( $p$ value of 0.023 ). However, when output is adjusted for waste scrap the picture changes radically. Column 2 of Table 7 shows that neither teamwork nor performance pay, nor the combination of the two, deliver significantly greater adjusted output. Adding teamwork to a unit with performance pay does not lead to significantly greater adjusted output ( $p$ value of 0.117 ). Similarly, adding performance pay to a unit with teamwork does not result in significantly greater adjusted output ( $p$ value of 0.094 ). Our results here run counter to the findings of Ichniowski et al. (1997) and Boning et al. (2007) for U.S. steel plants; we do not find evidence of genuine productivity gains in our particular German steel company through either teamwork or performance pay or the combination of these.

Column 3 of Table 7 reveals that the application of performance pay on its own is associated with longer machine running times (plus 2.2\%; again, both measures are normalized with their mean equal to zero). On its own, teamwork is associated with shorter running time (minus 4.1\%). Adding teamwork to a unit with performance pay has no statistically significant impact on operating time ( $p$ value of 0.108 from a Wald test). Adjusted running time takes account of down time required for unscheduled maintenance. Correcting for maintenance time (column 4 of Table 7), we find that teamwork, without performance-related pay, is associated with 
Figure 5. Box Plot of Adjusted Running Time by Type of Work Organization

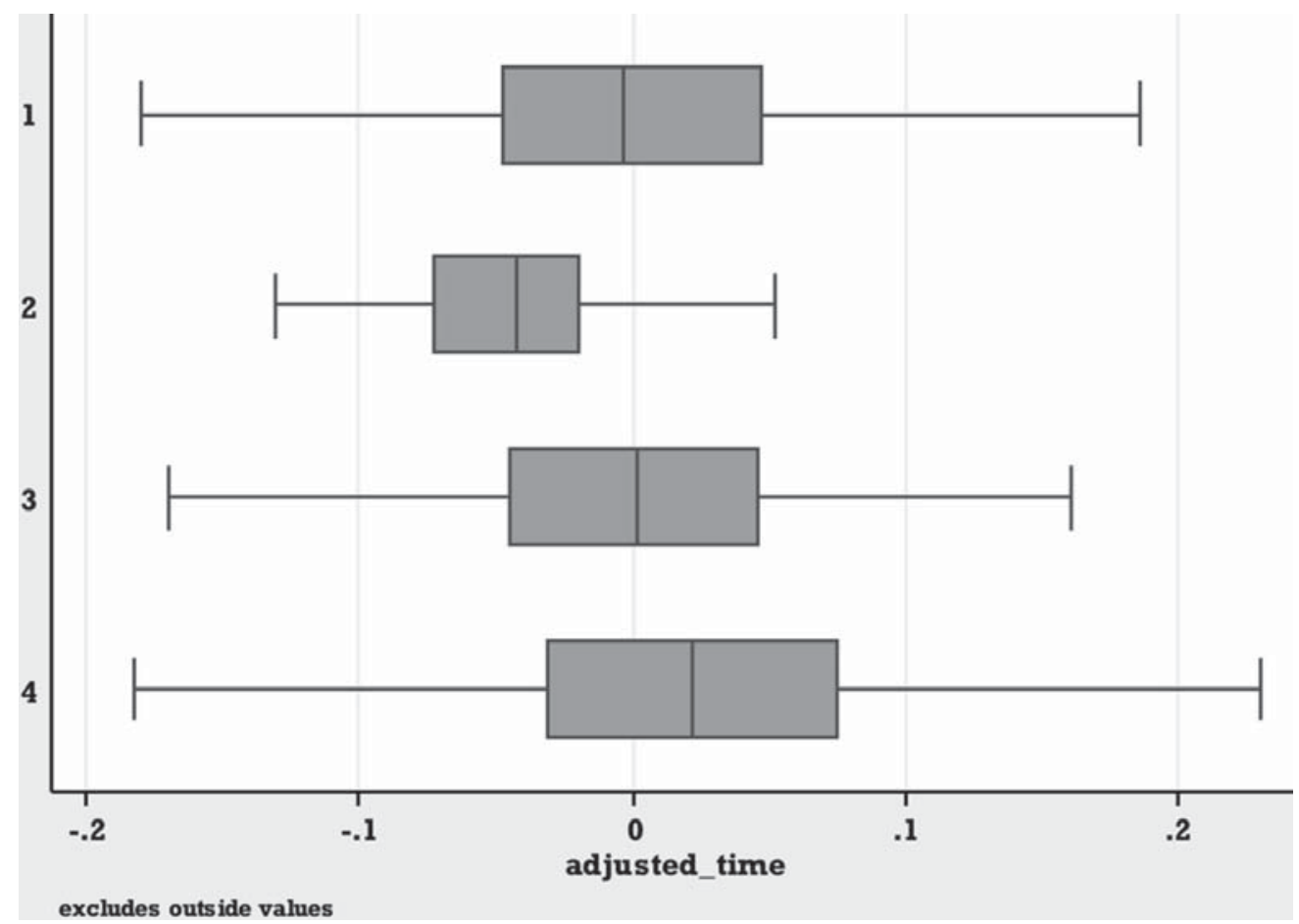

where $1=$ neither teamwork nor performance pay

$2=$ teamwork only

$3=$ performance pay only

$4=$ teamwork with performance pay

The mean differences of the normalized output and running time measures are always statistically significant:

Realized output: $\mathrm{F}=22.3, p<.01$

Adjusted output: $\mathrm{F}=18.0, p<.01$

Running time: $\mathrm{F}=13.6, p<.01$

Adjusted running time: $\mathrm{F}=3.2, p<.05$

lower adjusted running time (minus $5.4 \%$ ). Also, adding teamwork to a unit with performance pay leads to a significant loss of adjusted running time. Teamwork combined with performance pay results in adjusted running time of minus $4.1 \%$, compared with absence of each policy.

The 23 additional (and presumably less important) human resource management practices that have been introduced in Company X during the period under investigation and summarized in six different variables derived from factor analysis seem to have no clear-cut impact on either output or running time: While training and reorganization measures, organizational decentralization, and training and evaluation measures have a statistically significant yet economically moderate positive effect on gross output, this effect is statistically significant but negative for the former two variables in the remaining three models (adjusted output, running time, and adjusted running time). The coefficients of evaluation and quality management measures, new performance metrics, and reallocation of technical 
Table 7. Impact of Teamwork and Performance Pay on Output and Running Time

\begin{tabular}{lcccc}
\hline Variable & $\begin{array}{c}\text { Realized } \\
\text { output }\end{array}$ & $\begin{array}{c}\text { Adjusted } \\
\text { output }\end{array}$ & $\begin{array}{c}\text { Running } \\
\text { time }\end{array}$ & $\begin{array}{c}\text { Adjusted } \\
\text { running time }\end{array}$ \\
\hline Tenure & 0.003 & 0.033 & -0.006 & -0.0011 \\
& $(0.91)$ & $(3.41)$ & $(-1.69)$ & $(-2.02)$ \\
Performance pay only & $\mathbf{0 . 0 1 8}$ & 0.006 & $\mathbf{0 . 0 2 2}$ & -0.001 \\
& $\mathbf{( 3 . 6 1 )}$ & $(0.35)$ & $\mathbf{( 3 . 4 5 )}$ & $(-0.11)$ \\
Teamwork only & 0.011 & -0.023 & $\mathbf{- 0 . 0 4 1}$ & $\mathbf{- 0 . 0 5 4}$ \\
& $(1.18)$ & $(-0.72)$ & $\mathbf{( - 3 . 3 5 )}$ & $\mathbf{( - 3 . 0 2 )}$ \\
Teamwork with performance pay & $\mathbf{0 . 0 3 4}$ & 0.033 & 0.011 & $-\mathbf{0 . 0 4 1}$ \\
& $\mathbf{( 4 . 9 9 )}$ & $(1.46)$ & $(1.24)$ & $\mathbf{( - 2 . 6 2 )}$ \\
Factor 1: Training and Reorganization & 0.018 & -0.044 & -0.022 & -0.034 \\
& $(3.03)$ & $(-2.18)$ & $(-2.84)$ & $(-2.64)$ \\
Factor 2: Organizational Decentralization & 0.013 & -0.063 & -0.024 & -0.038 \\
Factor 3: Training and Evaluation & $(2.18)$ & $(-3.19)$ & $(-3.22)$ & $(-3.26)$ \\
& 0.013 & 0.034 & 0.013 & -0.007 \\
Factor 4: Evaluation and Quality Management & $(6.92)$ & $(5.19)$ & $(5.38)$ & $(-1.72)$ \\
& -0.000 & -0.036 & -0.017 & 0.003 \\
Factor 5: New Performance Measures & $(-0.11)$ & $(-5.26)$ & $(-6.26)$ & $(0.64)$ \\
& 0.002 & 0.010 & 0.011 & -0.015 \\
Factor 6: Reallocation of Technical Staff & $(0.95)$ & $(1.86)$ & $(4.91)$ & $(-2.32)$ \\
& -0.001 & -0.015 & -0.019 & -0.008 \\
$\mathrm{R}^{2}$ & $(-0.44)$ & $(-2.01)$ & $(-6.51)$ & $(-1.83)$ \\
$\mathrm{N}$ & 0.080 & 0.087 & 0.149 & 0.098 \\
\hline
\end{tabular}

Notes: Dependent variables are as noted in column headings. Estimates are from fixed effects regressions with dummy variables for month, year, and reconstruction of production sites $(n=4)$ to account for worker accommodation and learning. Controlling for the size of the production units by, e.g., hours of work is not possible because that information is missing in this second data set; $t$-statistics in parentheses.

staff exhibit a similar inconsistent pattern across the four models (4 out of 12 coefficients are not statistically significant and 6 of the statistically significant 8 coefficients have the "wrong" sign, indicating a negative instead of a positive impact on either output or running time). ${ }^{17}$

Overall, the results from Table 7 suggest that teamwork and performance pay provide incentives to workers to raise production quantity at the expense of quality and also serve to run the machines for longer hours instead of spending sufficient time on maintenance. The steel company has used gross output as its measure by which performance pay is calculated and this appears to have been a mistaken policy, because "people respond as strongly to badly designed incentives as they do to well-structured ones. And when those badly designed incentives are strong, they can lead to really egregious

\footnotetext{
${ }^{17}$ Additional estimations (not reported here but available from the authors on request) reveal that, first, the main effects (i.e., teamwork and bonus payments) are statistically insignificant in most cases (6 out of 8 coefficients fail to reach statistical significance) when a linear time trend is introduced in the estimations. Second, interacting the joint effect of teamwork and bonus payments with a linear and a quadratic time trend indicates that in two models (running time and adjusted running time) the effect is initially negative but becomes positive after some "learning period" of 84 and 95 months. This seems to suggest that the costs of implementing certain human resource management practices may have been underestimated so far.
} 
forms of behavior, and the results can then be horrendous" (Roberts 2010: $125)$.

\section{Conclusions}

Our empirical results cast considerable doubt on the alleged benefits to manufacturing firms from teamwork and performance-related pay. In terms of productivity enhancement, we find that gains from these human resource policies disappear once a correction to output is made for non-useable scrap. A quality-adjusted measure of output does not reveal benefits from teamwork or performance-related pay or a combination of the two. Moreover, the impact of these practices on adjusted running time (i.e., running time corrected for unscheduled maintenance work) is again statistically significant and negative. We also found some evidence of hidden costs of a combination of human resource management practices in the form of higher absence rates. Taken together, our results question the benefits of new human resource management practices and suggest that managers should devote greater consideration to potential or actual hidden costs of incentive-based policies. ${ }^{18}$ In our case, it appears that individual human resource policies can reduce absenteeism but, either singly or jointly, fail to raise adjusted output.

Interestingly, when our empirical results were shown to Company X, its management expressed surprise and launched an investigation into its human resource management policies. Unfortunately, the company was unwilling to support a follow-up academic study. Nevertheless, it would be desirable to undertake further empirical research to cross-check our findings against data from other companies, in both manufacturing and service sectors, in Germany and elsewhere.

${ }^{18}$ We agree with Kalmi, Jones, and Kauhanen (2008: 29) that econometric case studies have higher construct validity and internal validity than competing approaches, but there are doubts about their external validity. 


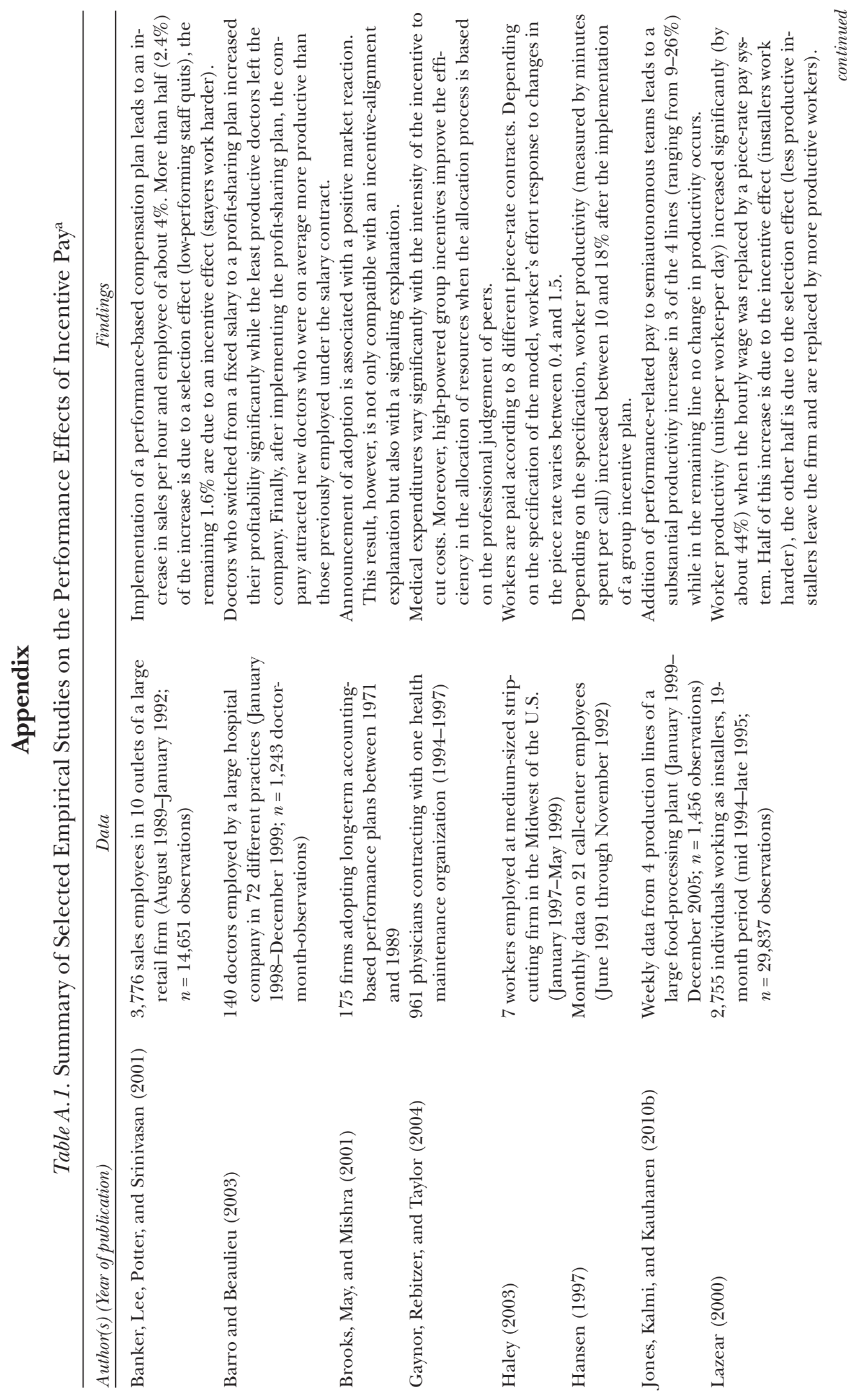




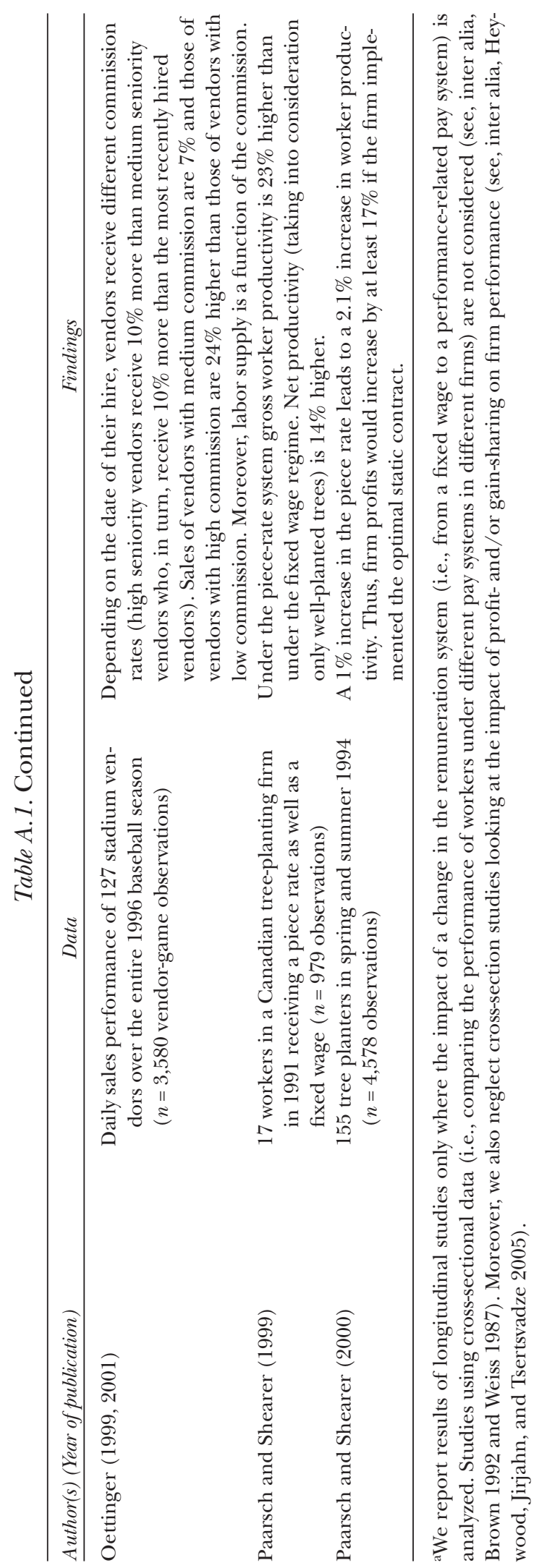




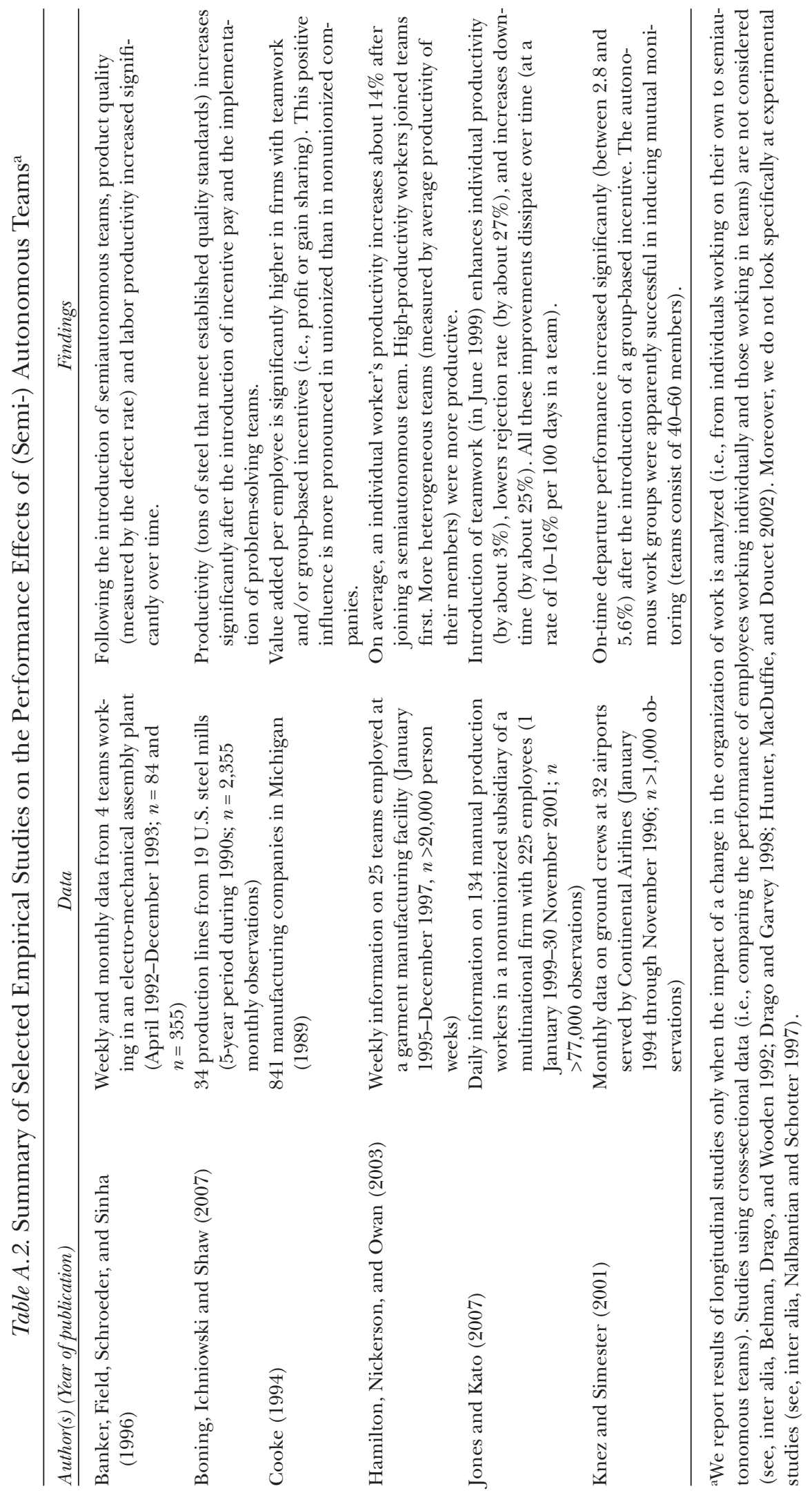




\section{References}

Arthur, Jeffrey B., and Lynda Aiman-Smith. 2001. Gainsharing and organizational learning: An analysis of employee suggestions over time. Academy of Management Journal 44: 737-54.

Baetschmann, Gregori, Kevin Staub, and Rainer Winkelmann. 2011. Consistent estimation of the fixed effects ordered logit model. IZA Discussion Paper No. 5443. Bonn: Institute for the Study of Labor.

Banker, Rajiv D., Joy M. Field, Roger G. Schroeder, and Kingshuk K. Sinha. 1996. Impact of work teams on manufacturing performance: A longitudinal field study. Academy of Management Journal 39: 867-90.

Banker, Rajiv D., Seok-Young Lee, Gordon Potter, and Dhinu Srinivasan. 2001. An empirical analysis of continuing improvements following the implementation of a performance-based compensation plan. Journal of Accounting and Economics 30: 315-50.

Barmby, Tim, and Gesine Stephan. 2000. Worker absenteeism: Why firm size may matter. Manchester School 68: 568-77.

Barro, Jason, and Nancy Beaulieu. 2003. Selection and improvement: Physician responses to financial incentives. NBER Working Paper No. 10017. Cambridge, MA: National Bureau of Economic Research.

Belman, Dale, Robert Drago, and Mark Wooden. 1992. Workgroups, efficiency wages and work effort. Journal of Post Keynesian Economics 14: 497-521.

Black, Sandra E., and Lisa M. Lynch. 2004. What's driving the new economy: The benefits of workplace innovation. Economic Journal 114: 97-116.

Bloom, Nicholas, and John Van Reenen. 2007. Measuring and explaining management practices across firms and countries. Quarterly Journal of Economics 122: 1351-1408.

Bloom, Nicholas, and John Van Reenen. 2010. Human resource management and productivity. NBER Working Paper No. 16019. Cambridge, MA: National Bureau of Economic Research.

Boning, Brent, Casey Ichniowski, and Kathryn Shaw. 2007. Opportunity counts: Teams and the effectiveness of production incentives. Journal of Labor Economics 25: 613-50.

Brooks, Raymond M., Don O. May, and Chandra S. Mishra. 2001. The performance of firms before and after they adopt accounting-based performance plans. Quarterly Review of Economics and Finance 41: 205-22.

Brown, Charles. 1992. Wage levels and method of pay. Rand Journal of Economics 23: 366-75.

Bundesministerium für Arbeit und Sozialordnung. 2001. Sicherheit und Gesundheit bei der Arbeit 2000: Unfallverhütungsbericht Arbeit. Bonn: Bundesministerium für Arbeit und Sozialordnung.

Cappelli, Peter, and David Neumark. 2001. Do "high-performance" work practices improve establishment-level outcomes? Industrial and Labor Relations Review 54: 737-75.

Chamberlain, Gary. 1980. Analysis of covariance with qualitative data. Review of Economic Studies 47: 225-38.

Cooke, William N. 1994. Employee participation programs, group-based incentives, and company performance: A union-nonunion comparison. Industrial and Labor Relations Review 47: 594-609.

Dickerson, Andy, Arne Risa Hole, and Luke Munford. 2011. A Review of Estimators for the Fixed Effects Ordered Logit Model. UK Stata Users Group Meeting. Accessed at http:// repec.org/usug2011/UK11_Hole.pdf.

Drago, Robert, and Gerald T. Garvey. 1998. Incentives for helping on the job: Theory and evidence. Journal of Labor Economics 16: 1-25.

Gaynor, Martin, James B. Rebitzer, and Lowell J. Taylor. 2001. Incentives in HMOs. NBER Working Paper No. 8522. Cambridge, MA: National Bureau of Economic Research.

- 2004. Physician incentives in health maintenance organizations. Journal of Political Economy 112: 915-31.

Gibbons, Robert. 1998. Incentives in organizations. Journal of Economic Perspectives 12: 115-32.

- 2005. Incentives between firms (and within). Management Science 51: 2-17.

Glassop, Linda I. 2002. The organizational benefits of teams. Human Relations 55: 225-49. 
Haley, M. Ryan. 2003. The response of worker effort to piece rates: Evidence from the Midwest logging industry. Journal of Human Resources 38: 881-90.

Hamilton, Barton H., Jack A. Nickerson, and Hideo Owan. 2003. Team incentives and worker heterogeneity: An empirical analysis of the impact of teams on productivity and participation. Journal of Political Economy 111: 465-97.

Hansen, Daniel G. 1997. Worker performance and group incentives: A case study. Industrial and Labor Relations Review 51: 37-49.

Heywood, John S., and Uwe Jirjahn. 2004. Teams, teamwork and absence. Scandinavian Journal of Economics 106: 765-82.

Heywood, John S., Uwe Jirjahn, and Georgi Tsertsvadze. 2005. Getting along with colleagues-Does profit-sharing help or hurt? Kyklos 58: 557-73.

Hunter, Larry W., John Paul Macduffie, and Lorna Doucet. 2002. What makes teams take? Employee reactions to work reform. Industrial and Labor Relations Review 55: 448-72.

Huselid, Mark A., and Brian E. Becker. 1998. High performance work systems and firm performance: A synthesis of research and managerial implications. Research in Personnel and Human Resources Management 16: 53-101.

Ichniowski, Casey, and Kathryn Shaw. 2003a. Beyond incentive pay: Insiders' estimates of the value of complementary human resource management practices. Journal of Economic Perspectives 17: 155-80.

—. 2003b. Connective capital: Building problem-solving networks within firms. Unpublished paper.

- 2009. Insider econometrics: Empirical studies of how management matters. NBER Working Paper No. 15618. Cambridge, MA: National Bureau of Economic Research.

Ichniowski, Casey, Kathryn Shaw, and Giovanna Prennushi. 1997. The effects of human resource management practices on productivity: A study of steel finishing lines. American Economic Review 86: 291-313.

Ichniowski, Casey, Thomas A. Kochan, David Levine, Craig Olson, and George Strauss. 1996. What works at work? Overview and assessment. Industrial Relations 35: 299-333.

Jirjahn, Uwe. 2002. The German experience with performance pay. In Michelle Brown, John S. Heywood, and Daniel J. B. Mitchell (Eds.), Paying for Performance: An International Comparison, pp. 148-78. Armonk, NY: M.E. Sharpe.

Jones, Derek C., Panu Kalmi, and Antti Kauhanen. 2006. Human resource management policies and productivity: New evidence from an econometric case study. Oxford Review of Economic Policy 22: 526-38.

- 2010a. How does employee involvement stack up? The effects of human resource management policies on performance in a retail firm. Industrial Relations 49: 1-21.

- 2010b. Teams, incentive pay, and productive efficiency: Evidence from a food-processing plant. Industrial and Labor Relations Review 63: 606-26.

Jones, Derek C., and Takao Kato. 2007. The impact of teams on output, quality and downtime: An empirical analysis using individual panel data. IZA Discussion Paper No. 2917. Bonn: Institute for the Study of Labor.

Kalmi, Panu, Derek C. Jones, and Antti Kauhanen. 2008. Econometric case studies: Overview and evidence from recent Finnish studies. Working Paper 458. Helsinki: Helsinki School of Economics.

Kandel, Eugene, and Edward P. Lazear. 1992. Peer pressure in partnerships. Journal of Political Economy 100: 801-17.

Kaufman, Roger T. 1992. The effects of IMPROSHARE on productivity. Industrial and Labor Relations Review 45: 311-22.

Knez, Marc, and Duncan Simester. 2001. Firm-wide incentives and mutual monitoring at Continental Airlines. Journal of Labor Economics 19: 743-72.

Küsgens, Ingrid, Christian Vetter, and Belgin Yoldas. 2001. Krankheitsbedingte Fehlzeiten in der deutschen Wirtschaft. In Bernhard Badura, Martin Litsch, and Christian Vetter (Eds.), Fehlzeiten-Report 2001, pp. 257-461. Berlin: Springer.

Lawler, Edward E., Susan A. Mohrman, and George Benson. 2001. Organizing for High Performance: Employee Involvement, TQM, Reengineering and Knowledge Management in the Fortune 100. San Francisco: Jossey-Bass. 
Lazear, Edward P. 2000. Performance pay and productivity. American Economic Review 90: 1346-61.

Lazear, Edward P., and Michael Gibbs. 2009. Personnel Economics in Practice. New York: John Wiley and Sons.

Lazear, Edward P., and Kathryn Shaw. 2007. Personnel economics: The economists' view of human resources. Journal of Economic Perspectives 21: 91-114.

Milgrom, Paul, and John Roberts. 1995. Complementarities and fit: Strategy, structure, and organizational change in manufacturing. Journal of Accounting and Economics 19: 179-208.

Nalbantian, Haig R., and Andrew Schotter. 1997. Productivity under group incentives: An experimental study. American Economic Review 87: 314-41.

Neilson, William S. 2007. Personnel Economics. Upper Saddle River, NJ: Pearson Prentice Hall. Oberhofer, Harald, and Michael Pfaffermayr. 2009. Fractional response models-A replication exercise of Papke and Wooldridge (1996). Working Paper 2009-02. University of Innsbruck: Department of Economics.

Oettinger, Gerald S. 1999. An empirical analysis of the daily labor supply of stadium vendors. Journal of Political Economy 107: 360-92.

ㄴ. 2001. Do piece rates influence effort choices? Evidence from stadium vendors. Economics Letters 73: 117-23.

Paarsch, Harry J., and Bruce S. Shearer. 1999. The response of worker effort to piece rates: Evidence from the British Columbia tree-planting industry. Journal of Human Resources 34: 643-67.

2000. Piece rates, fixed wages, and incentive effects: Statistical evidence from payroll taxes. International Economic Review 41: 59-92.

Papke, Leslie E., and Jeffrey M. Wooldridge. 1996. Econometric models for fractional response variables with an application to $401(\mathrm{k})$ plan participation rates. Journal of Applied Econometrics 11: 619-32.

. 2008. Panel data methods for fractional response variables with an application to test pass scores. Journal of Econometrics 145: 121-33.

Petrescu, Alina I., and Robert Simmons. 2008. Human resource management practices and workers' job satisfaction. International Journal of Manpower 29: 651-67

Prendergast, Canice. 1996. What happens within firms? A survey of empirical evidence on compensation policies. NBER Working Paper No. 5802. Cambridge, MA: National Bureau of Economic Research.

1998. The provision of incentives in firms. Journal of Economic Literature 37: 7-63.

Roberts, John. 2010. Designing incentives in organizations. Journal of Institutional Economics 6 : 125-32.

Roy, Donald. 1952. Quota restrictions and goldbricking in a machine shop. American Journal of Sociology 57: 427-42.

- 1954. Efficiency and "the Fix": Informal intergroup relations in a piecework machine shop. American Journal of Sociology 60: 255-66.

Schuster, Michael. 1983. The impact of union management cooperation on productivity and employment. Industrial and Labor Relations Review 36: 415-30.

Shaw, Kathryn. 2009. Insider econometrics: A roadmap with stops along the way. Labour Economics 16: 607-17.

Wagner, John A., Paul A. Rubin, and Thomas J. Callahan. 1988. Incentive payment and nonmanagerial productivity: An interrupted time series analysis of magnitude and trend. Organizational Behavior and Human Decision Processes 42: 47-74.

Weiss, Andrew. 1987. Incentives and worker behavior: Some evidence. NBER Working Paper No. 2194. Cambridge, MA: National Bureau of Economic Research. 